\title{
Maintenance of Non-Timber Plants at Low Heights Increased the Solar Radiation Influx and Understory Vegetation Biomass in Woodlands
}

\author{
Shailes Bhattrai $^{a, b,{ }^{*}, \text { Uma Karki }}{ }^{a}$, Sanjok Poudel ${ }^{a, c}$, Bidur Paneru $^{a}$, and Nevershi Ellis ${ }^{a}$ \\ ${ }^{a}$ Tuskegee University, Tuskegee, AL 36088 \\ ${ }^{b}$ Currently in University of Georgia, Athens, GA 30602 \\ ${ }^{c}$ Currently in Virginia Polytechnic Institute and State University, Blacksburg, VA 24061
}

\begin{tabular}{l} 
M A N U S C R I P T I N F O \\
\hline Article history: \\
Received 11 June 2019 \\
Revised 28 June 2020 \\
Accepted 7 July 2020 \\
\hline Keywords: \\
Non-pine plants \\
Photosynthetically active radiation \\
Southern pines \\
Understory vegetation biomass
\end{tabular}

\begin{abstract}
A B S T R A C T
The vast coverage of woodlands in the southeast United States offers a great opportunity for grazing small ruminants. However, not much attention has been given to utilize these resources well. The objectives of the current study were to evaluate the potential of increasing the a) light influx to the woodland floor and b) understory vegetation biomass by altering the height of non-timber (non-pine) plants. The study was conducted in six woodland plots (0.4-ha each) consisting of southern pines, hardwoods, and numerous understory plant species. The non-pine plants were either left uncut (control) or cut to one of the heights from the ground: $0 \mathrm{~m}, 0.9 \mathrm{~m}$, and $1.5 \mathrm{~m}$ (treatments) in summer 2016. Kiko wethers (8) and Katahdin rams (5-6) were rotationally stocked in the study plots (3 plots per animal species) during 2017 and 2018. Photosynthetically active radiation (PAR) data were collected before and after stocking animals and the understory vegetation biomass samples were collected before stocking animals in the study plots. The PAR influx in areas that received cutting treatments increased by $413-1723 \%$ when measured before grazing, and by $543-2223 \%$ when measured after grazing compared to the control. Similarly, the productivity of understory vegetation biomass was $36-107 \%$ greater in the cutting treatment areas compared to the control. The findings suggest that the maintenance of non-pine plants at low heights can significantly increase the PAR influx to the woodland floor, thereby enhancing the productivity of understory vegetation and grazing opportunity for small ruminants.
\end{abstract}

(C) 2020 NAPA. All rights reserved.

Citation:

Bhattrai, S., Karki, U., Poudel, S., Paneru, B., \& Ellis, N. (2020). Maintenance of Non-Timber Plants at Low Heights Increased the Solar Radiation Influx and Understory Vegetation Biomass in Woodlands. Global Journal of Agricultural and Allied Sciences, 2(1), 18-24.

\section{Introduction}

Woodland occupies approximately one third (33\%) of the total land area in the United States (Bigelow \& Borchers, 2017). In the southeast United States, a major portion of land area $(61 \%)$ is occupied by woodlands (Bigelow \& Borchers, 2017). The type of woodland varies from upland hardwood, planted pine, natural pine, and bottomland hardwoods, to oakpine mix (Mcnulty et al., 2013). Alabama has approximately 9.3 million hectares of woodland; loblolly pine (Pinus taeda L.) dominates the woodland (38.5\%; approximately 3.64 million hectares) and the longleaf pine (Pinus palustris Mill.) occupies 4.4\% (approximately 400 thousand hectares) of the total woodlands (Hartsell, 2016). Alabama stands as the third state in the nation in terms of woodland coverage, which is largely utilized for timber production (Alabama Forestry Commission, 2017). Timber production is a long-term activity that requires numerous years for the final harvest. The fast-growing pine-tree species, such as loblolly pine can be harvested in 25-40 years and can take up to 50 years (Cunningham, Barry, \& Walkingstick, 2009). However, the slow-growing species, such as longleaf pine takes much longer (40-50 years) for timber harvest (North Carolina Forest Service, 2011). Thus, the solo pine timber production approach for such a long time provides a limited income option to farmers and landowners (Karki, Karki, Khatri, \& Tillman, 2018a). One of the ways to increase the income from such operation is by adopting silvopasture practices (Karki et al., 2018a). When silvopasture is not suitable or undesired, woodlands can be managed for grazing with small ruminants to generate regular short-term incomes while waiting for trees to be ready for timber harvest. The availability of numerous non-pine plants in woodlands supports small ruminant integration because of their greater preference for such species compared to large ruminants like cattle (Sanon, KaboréZoungrana, \& Ledin, 2007).

Woodland grazing has two major benefits: 1) it provides forages for grazing animals, thereby reducing feeding costs and 2) it decreases the cost of woodland management and improves woodland health. Meat goats and

* Corresponding author. E-mail address: bhattaraishailes@gmail.com 
sheep are commonly raised in Southeastern states, including Alabama. Meat goats comprise $92 \%$ of the total goats (49 thousand head) in Alabama (USDA-NASS, 2019). Similarly, more than 24 thousand head of sheep are raised in 1060 farms in Alabama (USDA-NAAS, 2019). Karki, Gurung, Elliott, Karki, and Bolden-Tiller (2011) reported that most of the goat producers in Alabama were small farmers with a median herd size of 18 goats and average pasture holding of four hectares, which were dominated with seasonal grasses. This situation warrants the requirements of much supplementary feedstuff to sustain animals throughout the year, resulting in a very low or no profit. Farmers can reduce the production costs and increase profit by providing abundant grazing (Karki, 2014a.) and wider foraging options. Goats and sheep consume a diverse plant species, including woody browse available in woodlands.

Khatri, Karki, Bettis, and Karki (2016) reported that goats utilized 26 out of 37 plant species present in woodlands and created a browse line at an average height of $1.5 \mathrm{~m}$. Another study indicated that goats spent $68 \%$ of the total feeding time in shrubby areas and $32 \%$ in improved pastures (a portion of heathland upgraded in quality by sowing perennial ryegrass (Lolium perenne L.) and white clover (Trifolium repens L.)) (Benavides et al., 2009). In contrast, study with sheep in the same site showed that they spent $65 \%$ of the total feeding time grazing in the improved pastures versus $35 \%$ of feeding time grazing in shrubby areas. When goats were stocked in oak (Quercus spp. L.) forest stands, they consumed $45 \%$ oak browse, $22 \%$ other woody browse, and 33\% herbaceous species (Papachristou, Dziba, \& Provenza, 2005). Osoro et al. (2013) stated that sheep mostly consumed herbaceous vegetation as opposed to woody diets of goats when animals were stocked in three different heathland types: grass-dominated, gorse (Ulex gallii L.)-dominated, or heather (Calluna spp. L.)-dominated. When herbaceous vegetation was available, sheep grazed $99 \%$ of the total time reaching up to $0.75 \mathrm{~m}$ (Pfister, Malechek, \& Balph, 1988), while other studies have highlighted that sheep browsed on woody plants when herbaceous plants were limited (Kronberg \& Malechek, 1997) and reached to $0.87 \mathrm{~m}$ for browsing (Sanon et al., 2007). The grazing and browsing activities of animals also promotes woodland health by reducing the fuel buildup for potential fire hazards.

Goats reduced the brush cover from $45 \%$ to $15 \%$ in a year with an estimated cost of $\$ 33 /$ ha, sheep took three years to bring about the same result with an estimated cost of \$262/ha, while herbicide application cost was much higher to control brush at the same level as with animal grazing (\$593/ha) (Magadlela et al., 1995). Maggard and Barlow (2018) reported the cost of prescribed burning reached to $\$ 66 /$ ha and mechanical method of brush control to $\$ 348 /$ ha in woodlands. Goats have been recommended as an eco-friendly measure for brush control in several instances (Hart, 2001): clearing brush under power lines in New Hampshire, using goats to manage vegetation in forests by United States Forest Service in North Dakota, and as a cheap tool to control brush growth around the lakes by the Army Corps of Engineers. In addition, farmers can get regular incomes from the sale of animals, as woodland grazing extends feeding opportunities and reduces production costs (Karki, 2017). However, as stated earlier, small ruminants' capacity to utilize woodland vegetation would be limited to only certain heights $(0.75 \mathrm{~m}-0.87 \mathrm{~m}$ for sheep and $1.5 \mathrm{~m}$ for goats), leaving the foliage present above this height unused. There is a need to find out ways to maximize the productivity of understory vegetation and keep such growth within the reach of grazing animals. Cutting non-timber plants present in woodlands to lower heights can be one of the options to increase the influx of solar radiation to understory strata and promote understory vegetation growth.
The amount and spatial distribution of woodland canopy directly control light availability for understory vegetation (Lieffers, Messier, Stadt, Gendron, \& Comeau, 1999). Photosynthetically active radiation (PAR) is important for the growth and development of understory vegetation (Canham et al., 1990; Chen \& Klinka, 1997; Sims \& Pearcy, 1993). Drever and Lertzman (2003) found that tree thinning reduced the canopy cover, which thus increased sunlight to the understory vegetation in a douglas-fir forest (Pseudotsuga menziesii (Mirb.) Franco var. menziesii). Ishii, Maleque, and Taniguchi (2008) reported a more open canopy and a higher amount of solar radiation reaching the ground level by line thinning (25$29 \%$ stem density reduction) in Japanese cedar plantations (Cryptomeria japonica D. Don). These authors also found an increase in tree growth, understory vegetation diversity, and understory biomass due to thinning. Smith, Larson, Kelty, and Ashton (1997) stated that thinning increased the amount of incident light, minimized above and below-ground competition among residual trees, improved tree growth (stem diameter, crown size, and marketable volume), and reduced tree mortality.

Wienk, Hull, and Mcpherson (2004) reported a significant increase in the biomass in ponderosa pine (Pinus ponderosa Laws.) forest due to clearcutting (clear-cut plots: $1724 \mathrm{~kg} / \mathrm{ha}$ versus control plots: $5.8 \mathrm{~kg} / \mathrm{ha}$ ). Thinning or cutting of tree stands could result in increased light availability and promote the growth of understory vegetation layers (Lieffers et al., 1999). Practices like clear-cutting may be applicable to woodlands containing trees ready for final harvest; however, it may not be appropriate for woodlands consisting of young trees. In the latter case, cutting nontimber plant species to appropriate heights may be useful to improve canopy openness, increase understory vegetation yields, and tree growth in the long run. Nevertheless, information is lacking on appropriate understory vegetation heights to be readily utilized by small ruminants, and the effect of cutting non-timber plants on the dynamics of PAR and understory vegetation biomass in woodlands. The objective of this study was to evaluate the potential of increasing the a) light influx to woodland floor and b) understory vegetation biomass by altering the height of non-timber (nonpine) plants.

\section{Materials and Methods}

\subsection{Study Site}

The study was conducted during the fall of 2017 and summer and fall of 2018 at the Atkins Agroforestry Research and Demonstration Site, Tuskegee University, Tuskegee, Alabama, USA $\left(32^{\circ} 26^{\prime} 34.0^{\prime \prime} \mathrm{N}\right.$, $\left.85^{\circ} 43^{\prime} 57.4^{\prime \prime} \mathrm{W}\right)$. The summer (2018) was hot with an average maximum and minimum air temperatures of $33^{\circ} \mathrm{C}$ and $22^{\circ} \mathrm{C}$, respectively (Weather Underground, ND). Similarly, average maximum and minimum air temperatures were $26.6^{\circ} \mathrm{C}$ and $14.9^{\circ} \mathrm{C}$, respectively, in fall 2017 , and $29.9^{\circ} \mathrm{C}$ and $19.1^{\circ} \mathrm{C}$, respectively, in fall 2018 . The study site consisted of six woodland plots ( 0.4 ha each) with mixed southern pines (longleaf and loblolly), hardwood trees, and numerous understory vegetation (Table 1). The soil in the study site comprised of Cowarts loamy sand (78.7\%), Uchee loamy sand (21.3\%), and Uchee-Cowarts complex (0.1\%) with the slope ranging from 1 to 25 percent (USDA-NRCS, 2018).

The study plots had 12-13-years-old southern pine trees with an average tree density of 690 trees/ha and loblolly to longleaf pine ratio of 1.1. Loblolly pines $(n=157)$ had an average height of $8.6( \pm 0.11$ SE) $\mathrm{m}$ and diameter at breast height (DBH) of $14.2( \pm 0.33 \mathrm{SE}) \mathrm{cm}$. Similarly, longleaf pines $(n=173)$ had an average height of $8.1( \pm 0.11 \mathrm{SE}) \mathrm{m}$ and DBH of 11.2 
( $\pm 0.23 \mathrm{SE}) \mathrm{cm}$. Each plot was divided into four equal sections (0.1-ha each) with marking flags, and each section was randomly allocated with control or one of the cutting treatments. In the control section, the non-pine plants were left uncut (control; Zone 1). In the cutting-treatment sections, the nonpine plants were cut to one of the three heights: cut to the ground level ( 0 $\mathrm{m}$; Zone 2), $0.9 \mathrm{~m}$ from the ground level (Zone 3), and $1.5 \mathrm{~m}$ from the ground level (Zone 4) during the summer of 2016 (Fig. 1). Shelters, mineral feeders, and water troughs were placed in the open lanes that existed around the fence line (Zone 5), which had a limited shrubby growth. Once the vegetation grew back from the cut stubs and attained the full canopy, three sets of studies were conducted: one each in fall of 2017, and summer and fall of 2018 .

Table 1. List of plant species present in study plots at Atkins Agroforestry Research and Demonstration site, Tuskegee University, Tuskegee, Alabama, USA.

\begin{tabular}{|c|c|}
\hline Common name & Scientific name \\
\hline American beautyberry & Callicarpa americana $\mathrm{L}$. \\
\hline American holly & Ilex opaca Aiton var. opaca \\
\hline American pokeweed & Phytolacca americana $\mathrm{L}$. \\
\hline Bahiagrass & Paspalum notatum Flueggé var. notatum \\
\hline Blackberry & Rubus spp L. \\
\hline Broomsedge & Andropogon spp. L. \\
\hline Camphorweed & Heterotheca subaxillaris (Lam.) Britton \& Rusby \\
\hline Common boneset & Eupatorium perfoliatum $\mathrm{L}$. \\
\hline Common ragweed & Ambrosia artemisiifolia $\mathrm{L}$. \\
\hline Deerberry & Vaccinium stamineum $\mathrm{L}$. \\
\hline Dogfennel & Eupatorium capillifolium (Lam.) Small \\
\hline Eastern redcedar & Juniperus virginiana $\mathrm{L}$. \\
\hline Florida pusley & Richardia scabra $\mathrm{L}$. \\
\hline Gallberry & Ilex coriacea $\mathrm{L}$. \\
\hline Goldenrod & Oligoneuron spp. Small \\
\hline Grape vine & Vitis rotundifolia Michx. \\
\hline Greenbrier & Smilax spp. L. \\
\hline Hickory & Carya spp. Nutt. \\
\hline Honeysuckle & Lonicera spp. L. \\
\hline Loblolly pine & Pinus taeda $\mathrm{L}$. \\
\hline Longleaf pine & Pinus palustris Mill. \\
\hline Persimmon & Diospyros virginiana $\mathrm{L}$. \\
\hline Shrubby oak & Quercus nigra $\mathrm{L}$. \\
\hline $\begin{array}{l}\text { Smallflower } \\
\text { morningglory }\end{array}$ & Jacquemontia tamnifolia $\mathrm{L}$. \\
\hline Southern red oak & Quercus falcate Michx. \\
\hline Sparkleberry & Vaccinium arboreum Marshall \\
\hline Sumac & Rhus spp. L. \\
\hline Sweetgum & Liquidambar spp. L. \\
\hline Tropic croton & Croton glandulosus $\mathrm{L}$. \\
\hline Water oak & Quercus nigra L. \\
\hline Wild plum & Prunus americana Marsh. \\
\hline Winged elm & Ulmus alata Michx. \\
\hline Yaupon & Ilex vomitoria Aiton \\
\hline
\end{tabular}

\subsection{Study Animals}

The first set of the study was conducted using eight Kiko wethers and six Katahdin rams during the fall of 2017 (October-November, 29 days). Wethers were 38-40 months old and weighed 66 ( $\pm 1.7 \mathrm{SE}) \mathrm{kg}$. Katahdin rams were 19-22 months old and weighed $83( \pm 4.5 \mathrm{SE}) \mathrm{kg}$ at the start of the study in 2017. Similarly, the same Kiko wethers (8) and Katahdin rams (5) were used for the second set of the study in 2018; one ram was excluded from the study due to injury (Summer: June-August, 70 days and fall: September-October, 33 days). Wethers and rams were randomly allocated to separate plots ( 3 plots per animal species) at the beginning of the study in 2017, and rotationally stocked in those plots throughout the study periods in both years. The animals were allowed to graze one study plot at a time and moved to the next plot once $50 \%$ of the available vegetation within their reach was eaten. Available vegetation in each study plot was monitored by visual observation and by taking pictures using photoplots (USDA-FS, 1996) established in each zone before stocking animals and a couple of times during the study and comparing those pictures. Animals had free access to shelters, fresh water, and mineral mix throughout the study. The protocol of Tuskegee University Animal Care and Use Committee was followed when monitoring and taking care of animals daily.

\subsection{Photosynthetically Active Radiation (PAR)}

For collecting PAR data, a diagonal line across each treatment and control zone was established and 10 observation points were selected and marked with colored flags along the diagonal line spaced at equal distance from one another (Fig. 2). These points were used to collect the PAR data in all sets of studies. The PAR data were collected between 12:00-2:00 PM, when it was clear and sunny, for one minute in each observation point by using the LI-191 light quantum sensor (Li-COR Biosciences, NE, USA) that

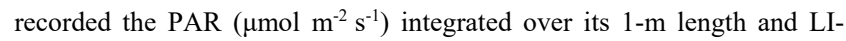
$\mathrm{COR}^{\circledR}$ LI-1500 light sensor logger that was set to automatically log the recorded data every six second (10 records per minute). The light sensor was placed on the ground surface and positioned at $90^{\circ}$ to the diagonal line at each observation point while collecting the data (Fig. 2). Two sets of data were collected: the first set within two days before animals were brought into each plot, and the second set within two days after animals were moved out of each plot in each rotation during all study periods (Table 2).

Table 2. Photosynthetically active radiation (PAR) measurement dates (before- and after-grazing) in study plots at Atkins Agroforestry Research and Demonstration site, Tuskegee University, Tuskegee, Alabama, USA.

\begin{tabular}{lllll}
\hline SN & Season & Plot\# & \multicolumn{2}{l}{ PAR Measurement Date } \\
& & & Before grazing & After grazing \\
\hline 1 & & 7 & 6-Oct-17 & 20-Oct-17 \\
2 & & 8 & 18 -Oct-17 & 30-Oct-17 \\
3 & Fall & 9 & $24-O c t-17$ & 5-Nov-17 \\
4 & 2017 & 10 & 24-Oct-17 & 5-Nov-17 \\
5 & & 12 & 18-Oct-17 & 30-Oct-17 \\
6 & & 13 & 6-Oct-17 & 20-Oct-17 \\
\hline 7 & & 7 & 2-Jun-18 & 4-Jul-18 \\
8 & & 8 & 3-Jul-18 & 11-Aug-18 \\
9 & Summer & 9 & 9-Aug-18 & 2-Sep-18 \\
10 & 2018 & 10 & 9-Aug-18 & 2-Sep-18 \\
11 & & 12 & 3-Jul-18 & 11-Aug-18 \\
12 & & 13 & 2-Jun-18 & 4-Jul-18 \\
\hline 13 & & 7 & 19-Sep-18 & 6-Oct-18 \\
14 & & 8 & 5-Oct-18 & 14-Oct-18 \\
15 & Fall & 9 & 13-Oct-18 & 23-Oct-18 \\
16 & 2018 & 10 & 13-Oct-18 & 23-Oct-18 \\
17 & & 12 & 5-Oct-18 & 14-Oct-18 \\
18 & & 13 & 19-Sep-18 & 6-Oct-18 \\
\hline
\end{tabular}

\subsection{Vegetation Biomass}

To determine the available vegetation biomass, vegetation samples were collected within two days prior to bringing animals to the study plots. Two 
random $1-\mathrm{m}^{2}$ quadrats per treatment and control were clipped to harvest $50 \%$ of the vegetation available up to the height of $1.7 \mathrm{~m}$. The maximum height of $1.7 \mathrm{~m}$ for collecting biomass samples was determined following Khatri (2016), who reported the average browsing height of young goats (6-11-month old) in woodlands as 1.5 to $1.6 \mathrm{~m}$. In this study, we added 0.1 $\mathrm{m}$ to account for the possible increment of browsing height of goats as they mature. At the beginning of the current study, goats were 2.5 years old. Collected vegetation samples were oven dried at $60^{\circ} \mathrm{C}$ for 72 hours and weighed to determine the vegetation dry matter.

\subsection{Data Analysis}

Vegetation biomass and PAR data were analyzed using the Mixed model in SAS v 9.4 (SAS Institute Inc., 2013). The available vegetation biomass for summer and fall 2018 were combined for statistical analysis as they did not differ between the two study periods (seasons). Vegetation biomass data were $\log$ transformed to meet the assumption of constant variance, and results (means and confidence limits) were back-transformed for presentation. The Tukey-Kramer test was used to determine the differences that existed among means at the significance $(\alpha)$ level of 0.05 . Replication (plot) was used as a random factor for both data sets. Cutting treatment, grazing, and their interaction were the source of variability for analyzing the PAR data; cutting treatment was used as the main effect for analyzing the biomass data. The general mixed models used to analyze PAR and vegetation biomass data are presented below.

Mixed model used for analyzing PAR data:

$Y_{i j k}=\mu+\alpha_{i}+\beta(\gamma)_{j k}+(\alpha \beta(\gamma))_{i j k}+e_{i j k}$

where, $Y_{\mathrm{ijk}}=$ value of an observation taken at $\mathrm{i}^{\text {th }}$ time in $\mathrm{j}^{\text {th }}$ zone and $\mathrm{k}^{\text {th }}$ season, $\mu=$ grand mean, $\alpha_{i}=$ main effect of $i^{\text {th }}$ time ( $i=1$-before or 2-after grazing), $\beta(\gamma)_{\mathrm{jk}}=$ main effect of $\mathrm{j}^{\text {th }}$ zone within $\mathrm{k}^{\text {th }}$ season $(\mathrm{j}=1-4, \mathrm{k}=1-3)$, $(\alpha \beta(\gamma))_{\mathrm{ijk}}=$ interaction effect of $\mathrm{i}^{\text {th }}$ time and $\mathrm{j}^{\text {th }}$ zone in $\mathrm{k}^{\text {th }}$ season, $\mathrm{e}_{\mathrm{ijk}}=$ an error associated with $\mathrm{i}^{\text {th }}$ time in $\mathrm{j}^{\text {th }}$ zone and $\mathrm{k}^{\text {th }}$ season.

Mixed model used for analyzing vegetation biomass data:

$Y_{i}=\mu+\alpha_{i}+e_{i}$

where, $Y_{i}=$ value of an observation taken at $\mathrm{i}^{\text {th }}$ zone, $\mu=$ grand mean, $\alpha_{i}=$ main effect of $i^{\text {th }}$ zone $(i=1-4)$, and $e_{i}=$ an error associated with the $i^{\text {th }}$ zone.

\section{Results and Discussion}

\subsection{Influence of Non-Pine Plant Height and Grazing on PAR Influx}

The influx of PAR on the woodland floor increased greatly in areas where non-pine plants were cut to different heights both before- and after-grazing as compared to the control ( $\mathrm{p}<0.0001)$ (Fig. 3a, b). The before-grazing PAR increment ranged from $413 \%$ in Zone 4 (1.5 m height) to $1723 \%$ in Zone 2 (plants cut to the ground level) as compared to the control $(p<0.0001)$ in fall 2017. Similar PAR increment pattern occurred in summer 2018 and fall 2018 , with the increment ranging from $411 \%$ in Zone 4 to $1570 \%$ in Zone 2 in the former and from $360 \%$ in Zone 4 to $1474 \%$ in Zone 2 in the latter study period compared to the control $(\mathrm{p}<0.0001)$. The increment in the after-grazing PAR was $543 \%$ in Zone 4 and $2223 \%$ in Zone 2 as compared to the control $(\mathrm{p}<0.0001)$ in fall 2017. Similar PAR increment patterns occurred during the studies conducted in summer and fall 2018.

The control area had dense woody species that created a two-tier canopy (overstory tree canopy and understory tall-growing plant canopy) that blocked the most PAR from penetrating through the system. Several studies have reported that reducing the denseness of woodlands and tree plantations by thinning and cutting exposed the canopy and increased sunlight influx to the ground floor. Ishii et al. (2008) reported that reducing the stand density by $25-29 \%$ increased the sunlight to the ground due to a more open canopy. Trentini et al. (2017) reported a significant increase in the canopy openness and solar radiation by thinning loblolly pine stands to $50 \%$ and $30 \%$ compared to the control, and the intensity of thinning was positively correlated to openness and solar radiation availability. Light availability as interception of PAR largely affects plant productivity (Monteith, 1977). Tall trees and shrubs capture most PAR, allowing very little or none to pass through the system and suppressing the understory growth (Belsky, 1994; Brezeanu, Pauca-Comanescu, \& Tacina, 1973). Reduction of tree canopy and basal cover is associated with increased light availability and understory yields in woodlands (Blair, 1971; Mcconnell \& Smith, 1970). The findings of the current study showed that the PAR influx to the woodland floor could be increased significantly by lowering the heights of non-pine plant species and without removing any timber tree, which is the main product of the system.

Vegetation defoliation activities by wethers and rams showed a significant effect on the incident PAR during all study periods $(\mathrm{p}<0.05)$. Wethers browsed on vegetation available up to $1.6 \mathrm{~m}$, but spent most of their feeding time in the vegetation strata 1.3-1.4 m. Unlike wethers, rams consumed foliage present within $1.1 \mathrm{~m}$, with the greatest feeding time spent in vegetation strata $0-0.8 \mathrm{~m}$ (Bhattrai, 2019). These results indicate that goats favored to consume vegetation available within $1.4 \mathrm{~m}$, although they reached to higher heights in few instances. On the other hand, rams favored grazing from closer to the ground than goats. However, the browsing heights of animals may vary with the size and breed of animals, characteristics of plant community present in the grazing system, nutrient requirements, and their access to other sources of nutrients. In the current study, grazing increased the PAR influx greatly in all three cutting treatment zones $(2,3$, and 4$)$, where animals were more concentrated for feeding activities compared to the control zone, during all study periods $(\mathrm{p}<0.0001)$. Only a little increment in PAR influx occurred in Zone 1 in 2018 because of grazing $(\mathrm{p}<0.05)$ (Fig. 4). The grazing-induced increment in PAR influx to the woodland floor ranged from 29 to $95 \%$ in the cutting treatment zones. The range of such increment remained within $3-54 \%$ in the control area.

The after-grazing PAR was higher than the before-grazing in all cutting treatments (29-95\%) and control (3-54\%). Although the after-grazing data were collected few weeks after the before-grazing data while waiting for end of grazing in each plot in each rotation, the difference in PAR influx was mainly from the defoliation effect. Khatri et al. (2016), from woodland studies with goats, reported a reduction in vegetation cover from $3 \%$ (high level: $>1.5 \mathrm{~m}$ ) to $50 \%$ (ground level: $0-.9 \mathrm{~m}$ ), thereby facilitating canopy openness. Similarly, Perevolotsky and Haimov (1992) reported that goat grazing increased the vegetation openness (non-woody cover) by $39 \%$ compared to the control in a Quercus calliprinos and Phillyrea latifolia dominated Mediterranean woodlands in Israel. Although a significant increase in PAR influx on woodland floor was found in all treatments and control because of animal defoliation, the amount of PAR intercepted on the control floor (40-67 $\mu \mathrm{mol} \mathrm{m} \mathrm{m}^{-2} \mathrm{~s}^{-1}$ ) was much less compared to that recorded on treatment floors $\left(257-1205 \mu \mathrm{mol} \mathrm{m}^{-2} \mathrm{~s}^{-1}\right)$ in the current study. 
Greater increment in PAR in cutting treatment zones could be due to the higher utilization of available vegetation in treatment zones versus the control. Goats and sheep spent most of their grazing time in vegetation strata 1.3-1.4 m (Zones 3 and 4: 53-71\%) and 0-0.8 m (Zone 2: 40-61\%), respectively, and the least in the control (Zone 1, 2\%-14\%) (Bhattrai, 2019). Although, goats and sheep consumed some vegetation available up to 1.6 $\mathrm{m}$ and $1.1 \mathrm{~m}$, respectively, amount of time spent in control area with vegetation available at higher heights compared to the treatment areas was much less (1-7\% in control vs. $93-99 \%$ in treatments) (Bhattrai, 2019) causing less defoliation, and consequently resulting in a lower increment in PAR influx after grazing. This finding demonstrates that grazing with small ruminants in woodlands without maintaining the non-timber vegetation within the reach of these animals seriously limits the scope of woodland grazing.

\subsection{Influence of Non-Pine Plant Height on Understory Biomass}

The dry matter of understory vegetation was the highest in Zones 2 (1943 $\mathrm{kg} / \mathrm{ha})$ and $3(1756 \mathrm{~kg} / \mathrm{ha})(\mathrm{p}<0.001)$ and lowest in Zone $1(940 \mathrm{~kg} / \mathrm{ha})$ (Table 3 ). The dry matter production was greater by $36-107 \%$ in areas where non-pine plants were cut (Zones 2, 3, and 4) compared to the control (Zone 1).

Table 3. Dry matter of understory vegetation in different zones, summer and fall 2018 at Atkins Agroforestry Research and Demonstration site, Tuskegee University, Tuskegee, Alabama, USA.

\begin{tabular}{llll}
\hline \multirow{2}{*}{ Zone } & \multicolumn{2}{c}{$\begin{array}{l}\text { Vegetation dry matter } \\
\text { LSMeans (kg/ha) }\end{array}$} & \multicolumn{2}{c}{ Confidence limit } \\
Lower & Upper \\
\hline 1 & $940^{\mathrm{c}}$ & 838 & 1055 \\
2 & $1943^{\mathrm{a}^{* * *}}$ & 1731 & 2180 \\
3 & $1756^{\mathrm{a}}$ & 1566 & 1974 \\
4 & $1278^{\mathrm{b}}$ & 1138 & 1434 \\
\hline
\end{tabular}

LSMeans with different superscripts in a column differ $(\mathrm{p}<0.001)$. Zones 1 to 4 are defined in Figure 1.

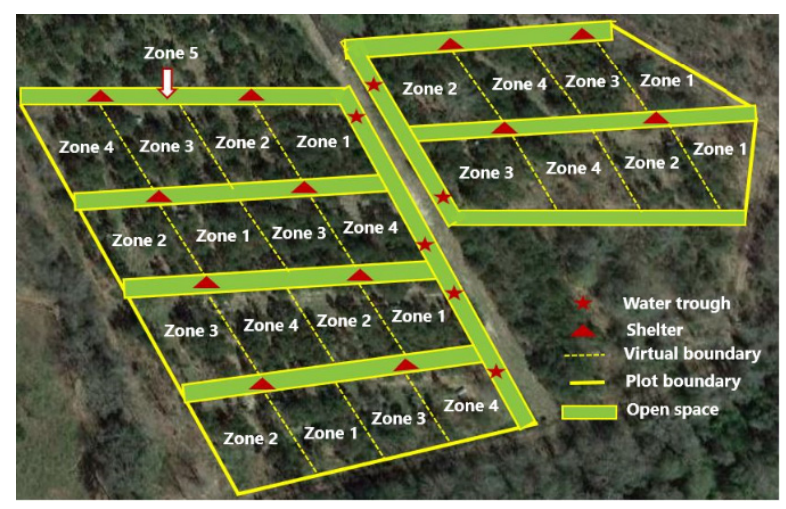

Figure 1. Diagram of research plots showing different zones, shelters, and water troughs, fall 2017 and summer and fall 2018 at Atkins Agroforestry Research and Demonstration site, Tuskegee University, Tuskegee, Alabama, USA.

Zone 1: Non-pine plants left uncut (control)

Zone 2: Non-pine plants cut to the ground level

Zone 3: Non-pine plants cut to $0.9 \mathrm{~m}$ from the ground level Zone 4: Non-pine plants cut to $1.5 \mathrm{~m}$ from the ground level Zone 5: Driveways around fences where shelters and water troughs were located

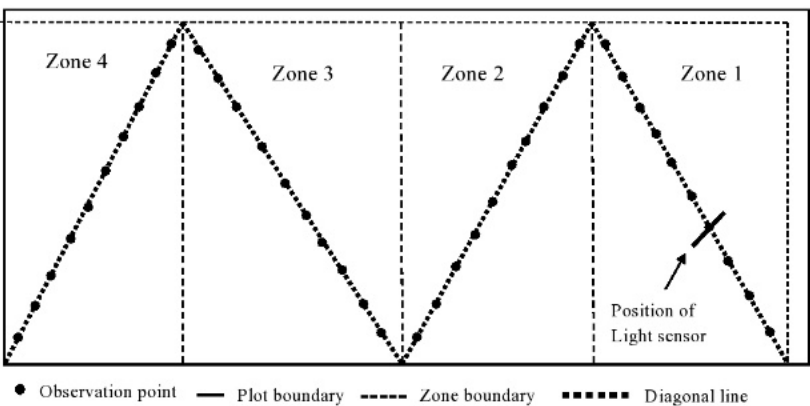

Figure 2. Schematic diagram of a study plot showing 10 observation points along the diagonal line in different zones to measure the photosynthetically active radiation (PAR) reaching to the woodland floor at Atkins Agroforestry Research and Demonstration site, Tuskegee University, Tuskegee, Alabama, USA. Zones 1 to 4 are defined in Figure 1.

(a) Before grazing

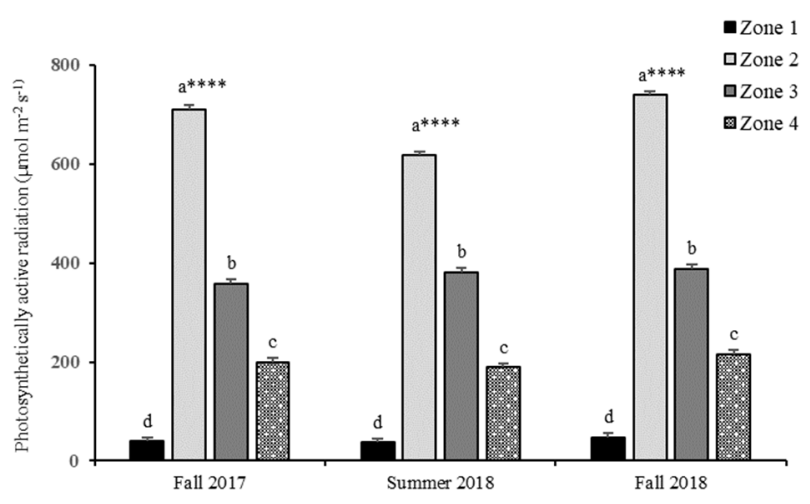

(b) After grazing

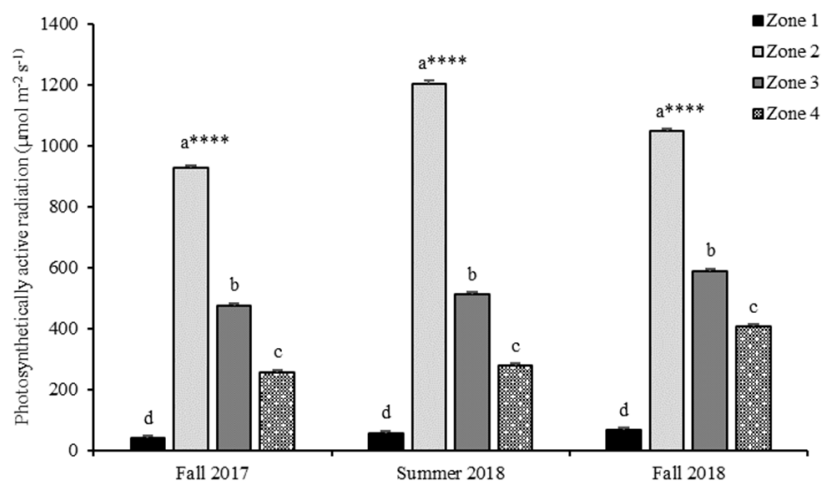

Figure 3. Influx of photosynthetically active radiation (PAR) (LSMeans $\pm \mathrm{SE}$ ) on the ground surface of different zones, before (a) and after (b) grazing in woodlands, fall 2017 and summer and fall 2018 at Atkins Agroforestry Research and Demonstration site, Tuskegee University, Tuskegee, Alabama, USA (****p<0.0001) (Each bar represents average PAR value from 12:00 PM to 2:00 PM). Zones 1 to 4 are defined in Figure 1. 


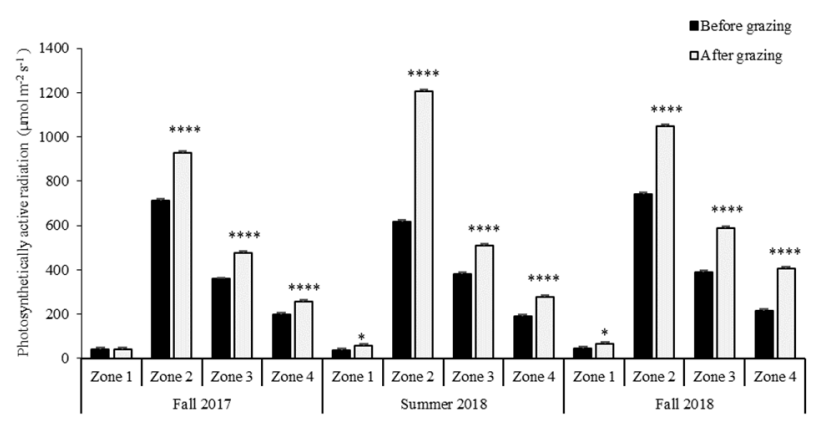

Figure 4. Influx of photosynthetically active radiation (PAR) (LSMeans \pm SE) on the ground surface of different zones before and after grazing in woodlands in fall 2017 and summer and fall 2018 at Atkins Agroforestry Research and Demonstration site, Tuskegee University, Tuskegee, Alabama, USA (*p<0.05, ****p<0.0001) (Each bar represents average PAR value from 12:00 PM to 2:00 PM). Zones 1 to 4 are defined in Figure 1.

The greater amount of PAR intercepted in treatments versus the control was clearly reflected in terms of the productivity of understory vegetation biomass in the current study. Compared to Zone 1 (control), the biomass production in Zones 2, 3, and 4 was greater by $107 \%, 87 \%$, and $36 \%$, respectively. Previous studies have reported an increased biomass production in the thinned plots compared to the control (non-thinned) plots. Wienk et al. (2004), based on their study in ponderosa pine forest, reported that the biomass production increased significantly $(\mathrm{p}<0.05)$ in clear-cut (similar to Zone 2 of this study) plots $(1724 \mathrm{~kg} / \mathrm{ha})$ compared to control (uncut) plots $(5.8 \mathrm{~kg} / \mathrm{ha})$. These authors further noted that the increased understory biomass was due to increased herbaceous species, which comprised more than $90 \%$ of the total understory biomass. Another study showed that thinning $50 \%$ trees increased the total understory biomass by nine times in western juniper (Juniperus occidentalis Hook.) woodlands (Bates, Miller, \& Svejcar, 2000). In the current study, we found the most growth of shrubs and herbaceous plants in Zone 2, where non-pine plants were cut to the ground level; whereas, the control area primarily consisted of woody species that developed canopies mostly beyond the reach of small ruminants $(\geq 1.7 \mathrm{~m})$. The current research, with desirable architecture of non-pine plants to facilitate needed PAR passing through the woodland canopy, showed the potential of increasing the productivity of understory biomass, and ultimately the carrying capacity of woodlands, by $107 \%$.

\section{Conclusions}

Strategically cutting the non-pine (non-timber) plants to maintain their canopy within the reach of small ruminants increased both PAR influx to the woodland floor (360-2223\%) and the understory vegetation biomass significantly $(36-107 \%)(\mathrm{p}<0.0001)$. The control area, which was highly dense with woody plants, received the least PAR reaching to the floor (37$\left.47 \mu \mathrm{mol} \mathrm{m} \mathrm{m}^{-2} \mathrm{~s}^{-1}\right)$ and produced the least understory biomass $(940 \mathrm{~kg} / \mathrm{ha})$. These results suggest that cutting of non-pine plants and maintaining their canopy within the comfortable reach of small ruminants significantly promote the understory vegetation biomass production and utilization, which ultimately increases the carrying capacity of the grazing system. Greater growth and better utilization of understory vegetation by small ruminants, as found in the current study, present a great potential of using woodland resources for supporting small ruminant production. Defoliation of understory vegetation by grazing animals may also enhance the growth of timber present in the system because of the reduced competition from non-timber species. Further studies are needed to evaluate the quality of understory foliage and performance of timber trees when non-timber plants are continuously maintained at low heights and managed with the rotational stocking of small ruminants. The findings of the current study will be applicable to the comparable woodland systems consisting of similar plantcommunity characteristics and similar breed and species of grazing animals integrated in the systems as described in this study.

\section{Acknowledgements}

The major fund for this study was obtained from the United States Department of Agriculture (USDA)-National Institute of Food and Agriculture (NIFA), Agriculture and Food Research Initiative (AFRI) Competitive Grant Number 2016-68006-24764, and a partial support was provided by the McIntire Stennis Forestry Research Program. The authors are grateful to the staffs of Tuskegee University George Washington Carver Agricultural Experiment Station and Cooperative Extension for their support to set up some of the grazing facilities. Authors highly appreciate Margaret Stephens and Alima Karki for their language edits on the manuscript.

\section{References}

Alabama Forestry Commission. (2017). Forest resource report 2017. Montgomery. Retrieved September 20, 2018, from http://www.forestry.alabama.gov/PDFs/AlabamaForestResourceReport.pdf

Alabama Meat Goat and Sheep Producers. (n.d.). Meat goats \& sheep fact sheet : Retrieved April 29, 2019, from http://alfafarmers.org/uploads/files/MeatGoatSheepFacts.pdf

Bates, J. O. N. D., Miller, R. F., \& Svejcar, T. J. (2000). Understory dynamics in cut and uncut western juniper woodlands. Journal of Range Management, 53(1), 119-126.

Belsky, A. J. (1994). Influences of trees on savanna productivity : Tests of Shade, Nutrients, and Tree-Grass Competition. Ecology, 75(4), 922-932.

Benavides, R., Celaya, R., Ferreira, L. M. M., Jáuregui, B. M., García, U., \& Osoro, K. (2009). Grazing behaviour of domestic ruminants according to flock type and subsequent vegetation changes on partially improved heathlands. Spanish Journal of Agricultural Research, 7(2), 417.

Bhattrai, S. (2019). Evaluating the use of small ruminants in woodlands: behavior, performance, and ecosystem impacts. Master's Thesis. Tuskegee University, AL.

Bigelow, D. P., \& Borchers, A. (2017). Major uses of land in the United States, 2012. Retrieved February 24, 2019, from https://ageconsearch.umn.edu/record/263079/files/eib-178.pdf

Blair, R. M. (1971). Forage production after hardwood control in a southern pine-hardwood stand. Forest Science, 17(3), 279-284.

Brezeanu, A., Pauca-Comanescu, M., \& Tacina, F. (1973). Influence of light on production and on some structure elements of the forest herbaceous layer. Revue roumaine de biologie. Serie de botanique, 83-95.

Canham, C. D., Denslow, J. S., Platt, W. J., Runkle, J. R., Spies, T. A., \& White, P. S. (1990). Light regimes beneath closed canopies and tree-fall gaps in temperate and tropical forests. Canadian Journal of Forest Research, 20(5), 620-631.

Chen, H. Y. H., \& Klinka, K. (1997). Light availability and photosynthesis of pseudotsuga menziesii seedlings grown in the open and in the forest understory. Tree Physiology, 17(1), 23-29.

Cunningham, K., Barry, J., \& Walkingstick, T. (2009). Managing Loblolly Pine Stands...from A to Z. Retrieved June 3, 2020, from https://www.uaex.edu/publications/PDF/FSA-5023.pdf 
Drever, C. R., \& Lertzman, K. P. (2003). Effects of a wide gradient of retained tree structure on understory light in coastal douglas-fir forests. Canadian Journal of Forest Research, 33(1), 137-146.

Hart, S. P. (2001). Recent perspectives in using goats for vegetation management in the USA. Journal of Dairy Science, 84(E. Suppl.), E170 E176.

Hartsell, A. (2016). Forests of Alabama, 2015. Asheville, NC. Retrieved September 21, 2019, from https://www.srs.fs.usda.gov/pubs/ru/ru_srs095.pdf

Ishii, H. T., Maleque, M. A., \& Taniguchi, S. (2008). Line thinning promotes stand growth and understory diversity in Japanese cedar (Cryptomeria japonica D. Don) plantations. Journal of Forest Research, 13(1), 73-78.

Karki, U. (2013a). Importance of year-round forage production and grazing/browsing management. In U. Karki (Ed.), Sustainable Year-Round Forage Production and Grazing/Browsing Management for Goats in the Southern Region (TUAG0213-0 ed., pp. 1-4). Tuskegee: Tuskegee University Cooperative Extension Program. Retrieved March 31, 2019, from https://www.tuskegee.edu/Content/Uploads/Tuskegee/files/CAENS/TUCE $\mathrm{P} /$ Livestock program/Year-RoundPasture_Handbook (1).pdf

Karki, U. (2017). Woodland grazing notes with research highlights. Publication No. TUAG1017-01, Tuskegee University Cooperative Extension Program. Retrieved February 24, 2019, from https://www.tuskegee.edu/Content/Uploads/Tuskegee/files/CAENS/TUCE P/Livestock program/WoodlandGrazing.pdf

Karki, U., Gurung, N. K., Elliott, A., Karki, L. B., \& Bolden-Tiller, A. (2011). Current situation and further training needs: a case of master goat producers. Paper presented at the American Society of Animal ScienceADSA-ASAS 2011 Joint Annual Meeting, July 10-14, 2011, New Orleans, LA (United States). Journal of Animal Science 89 (E-Supplement 1). Retrieved May 28, 2019, from https://www.jtmtg.org/JAM/2011/abstracts/0040.PDF.

Karki, U., Karki, Y., Khatri, R., \& Tillman, A. (2018a). Diurnal behavior and distribution patterns of Kiko wethers in southern-pine silvopastures during the cool-season grazing period. Agroforestry Systems.

Khatri, R. (2016). Use of woodlands and browse as complementary to the yearround grazing system for goats. Master's thesis. Tuskegee University.

Khatri, R., Karki, U., Bettis, J., \& Karki, Y. (2016). Grazing with goats changed the woodland plant- species composition during summer. Professional Agricultural Workers Journal, 4(1, 10). Retrieved June 5, 2019, from https://tuspubs.tuskegee.edu/cgi/viewcontent.cgi? article $=1078 \& \operatorname{context}=\mathrm{p}$ awj

Kronberg, S. L., \& Malechek, J. C. (1997). Relationships between nutrition and foraging behavior of free-ranging sheep and goats. Journal of Animal Science, 75(7), 1756-1763.

Lieffers, V. J., Messier, C., Stadt, K. J., Gendron, F., \& Comeau, P. G. (1999). Predicting and managing light in the understory of boreal forests. Canadian Journal of Forest Research, 29, 796-811.

Magadlela, A. M., Debaan, M. E., Bryan, W. B., Prigge, E. C., Skousen, J. G., D'Souza, G. E., ... Flores, G. (1995). Brush clearing on hill land pasture with sheep and goats. Journal of Agronomy and Crop Science, 174, 1-8.

Maggard, A., \& Barlow, B. (2018). Costs \& trends of Southern forestry practices, 2016. Retrieved February 24, 2019, from http://www.afoa.org/PDF/n180312a.pdf

Mcconnell, B. R., \& Smith, J. G. (1970). Response of understory vegetation to ponderosa pine thinning in Eastern Washington. Journal of Range Management, 23(3), 208-212.

Mcnulty, S., Caldwell, P., Doyle, T. W., Johnsen, K., Liu, Y., Mohan, J., ... Sun, G. (2013). Forests and climate change in the southeast USA. In K.
Ingram, K. Dow, L. Carter, \& J. Anderson (Eds.), Climate of the Southeast United States: Variability, change, impacts, and vulnerability (pp. 165189). Washington, DC: Island Press. Retrieved February 24, 2019, from https://www.srs.fs.usda.gov/pubs/ja/2013/ja_2013_mcnulty_001.pdf

Monteith, J. L. (1977). Climate and the efficiency of crop production in Britain. Philosophical Transactions of the Royal Society of London. B, Biological Sciences, 281(980), 277-294.

North Carolina Forest Service (2011). The economics of long leaf pine management. Retrieved June 3, 2020, from https://ncforestservice.gov/publications/LongleafLeaflets/LL07.pdf

Osoro, K., Ferreira, L. M. M., García, U., Jáuregui, B. M., Martínez, A., Rosa García, R., \& Celaya, R. (2013). Diet selection and performance of sheep and goats grazing on different heathland vegetation types. Small Ruminant Research, 109(2-3), 119-127.

Papachristou, T. G., Dziba, L. E., \& Provenza, F. D. (2005). Foraging ecology of goats and sheep on wooded rangelands. Small Ruminant Research, 59(2-3 SPEC. ISS.), 141-156.

Perevolotsky, A., \& Haimov, Y. (1992). The effect of thinning and goat browsing on the structure and development of Mediterranean woodland in Israel. Forest Ecology and Management, 49(2968-E), 61-74.

Pfister, A. J. A., Malechek, J. C., \& Balph, D. F. (1988). Foraging behaviour of goats and sheep in the Caatinga of Brazil. Journal of Applied Ecology, 25(2), 379-388.

Sanon, H. O., Kaboré-Zoungrana, C., \& Ledin, I. (2007). Behaviour of goats, sheep, and cattle and their selection of browse species on natural pasture in a Sahelian area. Small Ruminant Research, 67, 64-74.

SAS Institute Inc. (2013). SAS® 9.4 Statements: Reference. SAS Institute Inc., Cary, NC:

Sims, D. A., \& Pearcy, R. W. (1993). Sunfleck frequency and duration affects growth rate of the understorey plant, Alocasia macrorrhiza. Functional Ecology, 7(6), 683-689.

Smith, D. M., Larson, B. C., Kelty, M. J., \& Ashton, P. M. S. (1997). The practice of silviculture: Applied Forest Ecology (No. Ed. 9). John Wiley and Sons, Inc.

Trentini, C. P., Campanello, P. I., Villagra, M., Ritter, L., Ares, A., \& Goldstein, G. (2017). Thinning of loblolly pine plantations in subtropical argentina : impact on microclimate and understory vegetation. Forest Ecology and Management, 384, 236-247.

USDA-FS (United States Department of Agriculture, Forest Service). (1996). Sampling vegetation attributes. Forest Service, Technical Reference 17344, Bureau of Land Management, Denver, Colorado. Retrieved April 10, 2019, from https://archive.org/details/samplingvegetati3619nati/page/n9

USDA-NASS (United States Department of Agriculture, National Agricultural Statistics Service). (2019). 2017 Census of Agriculture. Retrieved July 2, 2019, from https://www.nass.usda.gov/Publications/AgCensus/2017/Full_Report/Volu me_1,_Chapter_1_US/usv1.pdf

USDA-NRCS (United States Department of Agriculture, Natural Resources Conservation Service). (2018). Custom soil resource report for Macon County, Alabama. Retrieved February 18, 2018, from https://websoilsurvey.sc.egov.usda.gov/App/WebSoilSurvey.aspx

Weather Underground. (ND). Retrieved June 20, 2019, from https://www.wunderground.com/history/monthly/us/al/hopehull/KMGM/date/2018-6

Wienk, C. L., Hull, C., \& Mcpherson, G. R. (2004). Evaluating the role of cutting treatments, fire and soil seed banks in an experimental framework in ponderosa pine forests of the Black Hills, South Dakota. Forest Ecology and Management, 192, 375-393. 